JAMP: Jurnal Adminitrasi dan Manajemen Pendidikan

Volume 3 Nomor 4 Desember 2020, Hal : 379-388

Tersedia Online di http://journal2.um.ac.id/index.php/jamp/

ISSN 2615-8574 (online)

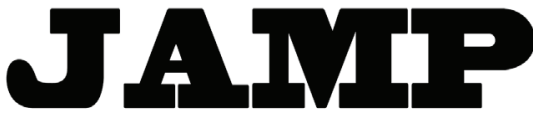

JURNAL ADMINISTRASI DAN MANAJEMEN PENDIDIKAN

\title{
PENINGKATAN PARTISIPASI ORANGTUA PESERTA DIDIK BERBASIS TEKNOLOGI INFORMASI
}

\author{
Argamas Viki Putra Malindo \\ Ali Imron \\ Raden Bambang Sumarsono \\ Jurusan Administrasi Pendidikan, Fakultas Ilmu Pendidikan \\ Universitas Negeri Malang, Jl. Semarang 5 Malang 65145 \\ argamasviki123@gmail.com
}

\begin{abstract}
This study aims to describe (1) the Go Application management process. (2) parental understanding in using Go Application as a forum for participation. (3) the impact of using Go Applications for schools and parents of students. (4) supporting factors in using Go Applications (5) inhibiting factors in using Go Applications and their solutions. (6) handling of obstacles in the use of Go Application. The research method used is qualitative, with a case study design in SMP Negeri 3 Malang. Data collected using observation techniques, in-depth interviews, and documentation. As for data analysis using a single case analysis technique. The results of this study include (1) the process of managing Go Applications including activities from planning, organizing, implementing, and evaluating. (2) parental understanding in using Go Application as a place of participation can facilitate the work of parents and schools, the existence of communication, and parents participate. (3) the positive impact of Go Applications, namely that school members are encouraged to use IT, assisted the learning process, is easy and shortens the time. Meanwhile, for the negative impact, the implementation process requires time and the use of mobile phones that do not fit the corridor. (4) supporting factors in the use of Go Application to increase the participation of students' parents by the potential of the school which includes the principal, the IT team, teachers, committees, parents, and students. (5) inhibiting factors in the use of Go Application and the solution there are passive parents, busy parents and there is a solution in the presence of communication and coming to school. (6) handling of obstacles in the use of Go Application by motivating, adding variety, having training, and appealing.
\end{abstract}

Keywords: improvement, parental participation, information technology

Abstrak: Penelitian ini bertujuan untuk mendeskripsikan (1) proses pengelolaan Go Aplikasi. (2) pemahaman orangtua dalam penggunaan Go Aplikasi sebagai wadah partisipasi. (3) dampak penggunaan Go Aplikasi bagi sekolah dan orangtua peserta didik. (4) faktor pendukung dalam penggunaan Go Aplikasi (5) faktor penghambat dalam penggunaan Go Aplikasi dan solusinya. (6) penanganan atas hambatan dalam penggunaan Go Aplikasi. Metode penelitian yang digunakan adalah kualitatif, dengan desain studi kasus di SMP Negeri 3 Malang. Data yang dikumpulkan menggunakan teknik observasi, wawancara mendalam, dan dokumentasi. Adapun untuk analisis data menggunakan teknik analisis kasus tunggal. Hasil penelitian ini meliputi (1) proses dalam pengelolaan Go Aplikasi meliputi kegiatan dari perencanaan, pengorganisasian, pelaksanaan, dan evaluasi. (2) pemahaman orangtua dalam penggunaan Go Aplikasi sebagai wadah partisipasi terdapat memudahkan pekerjaan orangtua dan sekolah, adanya komunikasi, dan orangtua berpartisipasi. (3) dampak positif adanya Go Aplikasi, yaitu warga sekolah terpacu menggunakan IT, terbantunya proses pembelajaran, mudah dan mempersingkat waktu. Sementara itu untuk dampak negatif adalah proses implementasinya membutuhkan waktu dan penggunaan handphone yang tidak sesuai koridor. (4) faktor pendukung dalam penggunaan Go Aplikasi untuk meningkatkan partisipasi orangtua peserta didik dengan adanya potensi sekolah yang meliputi kepala sekolah, tim TI, 


\begin{abstract}
guru, komite, orangtua, dan siswa. (5) faktor penghambat dalam penggunaan Go Aplikasi dan solusinya terdapat orangtua yang pasif, kesibukan orangtua dan terdapat solusi dengan adanya komunikasi dan datang ke sekolah. (6) penanganan atas hambatan dalam penggunaan Go Aplikasi dengan memotivasi, menambah variasi, adanya pelatihan, dan himbauan.
\end{abstract}

Kata Kunci: peningkatan, partisipasi orangtua, teknologi informasi

Era industri 4.0 hampir semua sendi kehidupan berbasis pada teknologi informasi dan komunikasi. Hasil penelitian peneliti terdahulu menunjukan bahwa teknologi informasi telah memungkinkah terjadinya individualisasi, akselerasi, pengayaan, perluasan, efektivitas dan produktivitas pembelajaran yang pada gilirannya akan meningkatkan kualitas pendidikan sebagai infrastruktur pengembangan sumber daya manusia (SDM) secara keseluruhan (Nugroho, 2014.). Sementara itu, Munir (2011:33) berpendapat bahwa peranan teknologi informasi dan komunikasi ada tiga yaitu: menggantikan peran manusia dengan melakukan kegiatan otomasi suatu tugas atau proses tertentu; memperkuat peran manusia yaitu menyajikan informasi, tugas, atau proses; melakukan restrukturisasi atau melakukan perubahan terhadap suatu tugas atau proses. Sedangkan menurut peneliti lainnya, dengan adanya teknologi informasi terdapat sebuah hambatan antara lain: (1) e-learning yang dapat pengalihfungsian dan mengakibatkan guru jadi tersingkirkan, (2) seringnya mengakses internet dikhawatirkan peserta didik menyalahgunakan, (3) peserta didik dapat terkena information overload, (4) peserta didik menjadi pecandu dunia maya secara berlebihan, (5) tindakan kriminal, (6) menimbulkan sikap apatis baik bagi peserta didik, guru, ataupun orangtua (Sudibyo, 2011).

Dalam dunia pendidikan terutama pada lembaga pendidikan atau sekolah, humas sangat berperan penting dalam meningkatkan mutu pada sekolah tersebut. Ada beberapa prinsip hubungan masyarakat yaitu: (1) melibatkan orang untuk tindakan yang bertanggung jawab dan menantang untuk kebaikan bersama, (2) memberikan pengalaman yang terstruktur untuk merefleksikan secara kritis, (3) mengartikulasikan layanan yang jelas dan tujuan pembelajaran untuk semua orang yang terlibat, (4) memungkinkan bagi mereka yang perlu mendefinisikan kebutuhan, (5) menjelaskan tanggung jawab setiap orang dan organisasi yang terlibat, (6) menyesuaikan penyedia layanan dan kebutuhan layanan melalui proses mengenali keadaan yang berubah, (7) memberi harapan komitmen organisasi yang tulus, aktif dan berkelanjutan, (8) menyertakan pelatihan, pengawasan, pemantauan, dukungan, pengakuan dan evaluasi untuk memenuhi tujuan layanan dan pembelajaran, (9) memastikan komitmen layanan dan pembelajaran fleksibel dan sesuai demi kepentingan bersama, (10) berkomitmen untuk berpartisipasi dalam program yang beragam (Gleason and Violette, 2012).

Partisipasi masyarakat dan orangtua merupakan hal yang penting dan sangat dibutuhkan dalam setiap kegiatan di sekolah. Pernyataan tersebut dipertegas oleh Raharja dalam Imron dan Sumarsono (2017) bahwa partisipasi orangtua dalam pendidikan tidak sekedar bersifat reaktif hadir di sekolah, namun lebih diharapkan bantuan informasi maupun hal yang biasa langsung memberi bantuan untuk mewujudkan pendidikan yang bermutu. Masyarakat dan orangtua kebanyakan bersikap kurang peduli dan jarang berperan terhadap kegiatan yang ada di sekolah. Kesibukan yang dimiliki orangtua merupakan salah satu alasan utama kurangnya partisipasi di sekolah. Pernyataan tersebut didukung oleh (Usman, 2014) yang mengatakan partisipasi masyarakat khususnya orangtua dalam penyelenggaraan pendidikan sangatlah kurang. Hasil penelitian terdahulu yang dilakukan oleh (Sumarsono, dkk (2016) mengenai partisipasi orangtua dalam meningkatkan kualitas sekolah dasar di kota Malang yakni dengan memanifestasikan aspek pembelajaran melalui kegiatan parenting day karena orangtua akan datang secara aktif di kegiatan tersebut untuk menjadi narasumber, menyiapkan program kunjungan lapangan, mengembangkan ruang kelas yang menginspirasi, mempersiapkan try out untuk kelas 6 bersama guru, merencanakan dan mengevaluasi kegiatan belajar di luar kelas.

Partisipasi orangtua merupakan keikutsertaan orangtua secara aktif baik langsung maupun tidak langsung dalam setiap kegiatan atau program sekolah. Menurut Wuriyanto dalam Benty dan Gunawan (2015) partisipasi orangtua adalah kontribusi, keterlibatan, dan sumbangan masyarakat dalam usaha untuk meningkatkan program mutu pendidikan. Sebagaimana yang dikemukakan oleh Olsen \& Fuller dalam Imron dan Sumarsono (2017) mengungkapkan bahwa partisipasi orangtua dapat dimaknai sebagai 
suatu proses aktif dan sebagai suatu kegiatan nyata apabila terpenuhi oleh ketiga faktor pendukungnya, yaitu: (1) adanya kemauan, (2) adanya kemampuan, dan (3) adanya kesempatan untuk berpartisipasi. Berdasarkan temuan penelitian yang dilakukan $(\mathrm{Ng}, 2013)$ ada empat fase perkembangan bagaimana orangtua termasuk dalam tata kerjasama sekolah yaitu antara lain orangtua sebagai tamu tak diundang yang berarti mereka datang ke sekolah untuk mendaftarkan anaknya ke sekolah; orangtua sebagai relawan (berpartisipasi); orangtua sebagai klien yaitu kerjasama yang dikeluarkan antara pihak sekolah dengan orangtua berkaitan dengan pendidikan anak; dan orangtua sebagai gubernur sekolah yang mempunyai tanggung jawab terhadap penyelenggaraan pendidikan di sekolah.

Partisipasi orangtua terhadap sekolah merupakan unsur penting dari sikap tanggung jawab, baik tanggung jawab keluarga maupun tanggung jawab sekolah. Dengan demikian antara sekolah dan orangtua harus dibina dan dikembangkan suatu hubungan yang harmonis untuk mewujudkan pendidikan yang bermutu (Sumarsono, 2018). Partisipasi masyarakat dan orangtua dalam pelaksanaan program pendidikan terdiri dari berbagai macam atau bentuk. Minarti (2012) mengungkapkan bahwa bentuk kerjasama antara sekolah dengan masyarakat dapat digolongkan menjadi 3 hal, yaitu: (1) hubungan edukatif, (2) hubungan kultural, (3) hubungan institusional. Sedangkan Cohen dan Uphoff (dalam Dwiningrum, 2011:61) membedakan partisipasi menjadi empat jenis, yaitu (1) partisipasi dalam pengambilan keputusan, (2) partisipasi dalam pelaksanaan, (3) partisipasi dalam pengambilan pemanfaatan, dan juga (4) partisipasi dalam evaluasi. Hasil penelitian Sumarsono (2018), mengungkapkan bahwa bentuk partisipasi orangtua dapat dibedakan menjadi 2, yaitu bentuk fisik dan non-fisik. Aktifitas partisiasi orangtua dalam bentuk fisik meliputi berupa tenaga yaitu pada kegiatan field trip, sumbangan pembangunan gedung sekolah, menumbuhkan nilai-nilai ketaqwaan dan semangat beribadah kepada para siswa melalui kegiatan gema dzulhijah dan gema ramadhan, membantu pengadaan sarana dan prasarana penujang pembelajaran, dan penggalangan pendanaan pendidikan, yang dilakukan secara optimal untuk peningkatan mutu pendidikan. Adapun aktivitas partisipasi orangtua dalam bentuk non-fisik berupa sebagai nara sumber pada kegiatan parenting day; memberikan ide, gagasan, saran ataupun kritikan baik melalui komite, paguyuban bahkan secara individu terhadap pelaksanaan kegiatan program sekolah; melalui komite dan paguyuban membantu dalam penyusunan program sekolah, melakukan koordinasi dalam meralisasikan program, dan mengevaluasi pelaksanaan program, sehingga membantu dalam upaya meningkatkan mutu pendidikan.

Sekolah pada dasarnya selalu berupaya untuk memperbaiki kualitas pendidikan melalui peningkatan partisipasi orangtua di sekolah. Salah satu cara memperbaiki tingkat partisipasi tersebut yaitu melalui program-program yang dibuat oleh pihak humas sekolah agar program humas bisa berjalan dengan baik, maka sekolah harus mengelola secara baik dan benar. Menurut Cutlip, dkk (2005) ada langkahlangkah yang harus dilakukan yaitu: (1) mendefinisikan masalah. (2) membuat rencana dan program (3) mengambil tindakan dan berkomunikasi. (4) mengevaluasi program. Benty dan Gunawan (2015) menyebutkan bahwa sekolah dalam meningkatkan partisipasi masyarakat dalam program pendidikan sekolah harus memahami tahapan dalam melaksanakan kerjasama dengan masyarakat. Sementara itu, hasil penelitian Sumarsono (2018) mengungkapkan bahwa upaya yang bisa dilakukan dalam memberdayakan partisipasi orangtua dengan menyusun dan melaksanakan program kegiatan sekolah yang bermanfaat bagi siswa dan menarik bagi orangtua untuk berpartisipasi, setiap aktivitas pelaksanaan program sekolah dengan melibatkan orangtua, mengembangkan iklim sekolah yang kondusif bagi terselenggaranya partisipasi orangtua, intensitas jalinan komunikasi dengan orangtua, dan menerapkan prinsip transparansi dan akuntabilitas.

Pada penelitian ini, peningkatan partisipasi orangtua berbasis teknologi informasi diwujudkan dalam bentuk Go Aplikasi yang dikembangkan oleh Tim Teknologi Informasi Sekolah Menengah Pertama (SMP) Negeri 3 Malang. Fitur yang terdapat pada Go Aplikasi antara lain berupa literasi online, info pembelajaran, modul pembelajaran, tanaman sekolah, inventaris laboratorium IPA, serta pengumuman yang bisa digunakan orangtua untuk mengetahui perkembangan dan keadaan anaknya di sekolah. Melalui Go Aplikasi ini, orangtua dapat berpartisipasi, baik pada tataran proses perencanaan, pelaksanaan, maupun pengawasan atau evaluasi program sekolah. 
Berdasarkan pemaparan tersebut, peneliti tertarik untuk melakukan kajian lebih lanjut tentang peningkatan partisipasi orangtua peserta didik berbasis teknologi informasi studi kasus pada SMP Negeri 3 Malang, dengan menggunakan pendekatan kualitatif. Adapun tujuan penelitian ini berupaya untuk mengungkap tentang (1) proses pengelolaan Go Aplikasi. (2) pemahaman orangtua dalam penggunaan Go Aplikasi sebagai wadah partisipasi, (3) dampak penggunaan Go Aplikasi bagi sekolah dan orangtua peserta didik, (4) faktor pendukung dalam penggunaan Go Aplikasi, (5) faktor penghambat dalam penggunaan Go Aplikasi dan solusinya, dan (6) penanganan atas hambatan dalam penggunaan Go Aplikasi.

\section{METODE}

Penelitian ini menggunakan pendekatan kualitatif dengan desain penelitian deskriptif. Jenis penelitian yang digunakan yaitu studi kasus yang berfokus pada kejadian. Kasus yang akan diteliti yaitu, penggunaan aplikasi untuk meningkatkan partisipasi orangtua. Aplikasi tersebut diprogram oleh Tim Teknologi Informasi sekolah. Penggunaan metode penelitian kualitatif, yaitu sebuah penelitian yang berfungsi untuk mendalami sebuah fenomena yang dialami oleh subjek penelitian yang dideskripsikan melalui bahasa dan kata-kata dalam konteks khusus yang alamiah dan menggunakan metode ilmiah.

Penelitian dilakuan di SMP Negeri 3 Malang yang terletak di Jalan Dokter Cipto 20, Kecamatan Klojen, Kota Malang. Sumber data dalam penelitian ini menggunakan data primer dan data sekunder. Data primer meliputi menggali informasi dari stakeholder sekolah. Sementara itu data sekunder adalah dokumentasi, di mana dokumen kemudian akan dianalisa dan digunakan sebagai bukti pendukung.

Pengumpulan data merupakan tahap penting dalam penelitian karena perolehan data yang diperoleh di lapangan akan digunakan dalam menganalisis hasil penelitian. Ada beberapa teknik yang digunakan oleh peneliti dalam penelitian ini, yaitu wawancara mendalam, observasi, dan studi dokumentasi.

\section{HASIL}

\section{Proses Pengelolaan Go Aplikasi untuk Meningkatkan Partisipasi Orangtua Peserta Didik}

Sekolah dalam membangun hubungan dengan masyarakat memiliki program yang melibatkan masyarakat. Program yang ada yaitu go aplikasi, khususnya program tersebut tidak terkecuali mempunyai prosedur atau langkah-langkah untuk menjalankannya. Dalam tahap perencanaan, sekolah berawal dari sebuah permasalahan atau keluhan yang disampaikan oleh salah satu guru mengenai program literasi yang masih manual, selain itu dari sebuah permasalahan dan dengan adanya potensi sekolah yang berbasis TI sekolah juga berkeinginan untuk memiliki sebuah branding yang dapat membuat citra sekolah dapat lebih baik. Pada tahap pengorganisasian, melakukan proses penyusunan struktur tim TI yang dikarenakan dipicu dengan adanya sebuah lomba yang diadakan di kota Malang sehingga pihak sekolah mempunyai inisiatif untuk membuat tim TI tetapi disesuaikan dengan keadaan real atau potensi yang ada.

Kemudian pada tahap pelaksanaan, sekolah mengundang orangtua peserta didik terlebih dahulu agar mereka dapat mengetahui apa yang disosialisasikan sekolah dan sekaligus menggunakannya pada saat sosialisasi. Sekolah juga memberikan pin terlebih dahulu kepada orangtua dan siswa agar bisa menggunakan dibeberapa fitur go aplikasi. Orangtua atau siswa yang sudah mempunyai pin baru bisa memulai untuk masuk di website sekolah dan memilih go aplikasi, serta mengoperasikan fitur go aplikasi. Dan yang terakhir tahap evaluasi, sekolah selalu mengadakan program evaluasi secara rutin baik setiap akhir tahun, akhir semester, ataupun setiap hari senin. Evaluasi yang dilakukan sekolah tidak selalu mengenai go aplikasi tetapi menyangkut semua permasalahan sekolah, jika terdapat masalah mengenai go aplikasi baru sekolah akan menyampaikan evaluasi mengenai hal tersebut. Pada saat evaluasi penggunaan perangkat go aplikasi ada dua macam yakni evaluasi software atau perangkat lunak seperti perangkat go aplikasi-nya sendiri dan evaluasi implementasi untuk mengevaluasi pada saat melaksanakan atau menjalanakan tersebut. 


\section{Pemahaman Orangtua dalam Penggunaan Go Aplikasi sebagai Wadah Partisipasi}

Sekolah dalam meningkatkan partisipasi orangtua tentunya memiliki sebuah ide atau terobosan baru sebagai wadah untuk memberikan pemahaman kepada orangtua agar lebih antusias dalam berpartisipasi. Begitu pula dengan SMP Negeri 3 Malang mempunyai ide atau terobosan baru untuk ditawarkan kepada orangtua peserta didik yaitu dengan menciptakan sebuah perangkat yang bernama go aplikasi yang berguna sebagai wadah partisipasi. Partisipasi orangtua dapat dikatakan berhasil ketika orangtua sudah memahami dan menggunakan perangkat go aplikasi yang diciptakan oleh sekolah.

Pendapat orangtua siswa dengan adanya perangkat go aplikasi di sekolah dapat mempermudah dan membantu pekerjaan baik orangtua dan sekolah, karena dengan adanya go aplikasi orangtua akan dapat memantau kegiatan pembelajaran yang ada di sekolah. Upaya orangtua yang berusaha memahami go aplikasi, orangtua datang ke sekolah untuk memahaminya lebih lanjut dan dengan berjalannya waktu orangtua dapat memahami dengan bantuan kepada yang lebih tahu. Kemudian orangtua memahami semua fitur yang ada di go aplikasi dan orangtua mulai menggunakan perangkat go aplikasi untuk memantau kegiatan pembelajaran di sekolah sebagai wadah partisipasinya.

\section{Dampak Penggunaan Go Aplikasi bagi Sekolah dan Orangtua Peserta Didik}

Berkaitan dengan faktor pendukung dan penghambat tentunya akan muncul sebuah dampak dari penggunaan go aplikasi yang ada di sekolah. Dari dampak tersebut tidak semuanya dapat menjadi dampak yang positif, tetapi ada juga dampak yang negatif. Dari dampak yang positif dapat dirasakan dengan semua warga sekolah dipacu untuk menggunakan TI, guru-guru dapat mengembangkan diri dengan memanfaatkan TI, terbantunya proses pembelajaran, mempersingkat waktu, dan yang dirasakan oleh orangtua yaitu mudahnya mendapat informasi dari sekolah. Sedangkan dari dampak negatif yang dirasakan sekolah sebenarnya bukan dampak negatif melainkan sebuah hambatan seperti dalam proses implementasinya membutuhkan waktu, penggunaan handphone yang tidak sesuai koridor jika tidak di kontrol di sekolah maupun di rumah dengan orangtua dan yang sekolah merasa kesulitan untuk mengevaluasi jika tidak ada saran-saran dari orangtua, serta orangtua yang bisa dianggap malas dan gaptek sehingga kurang memahami untuk penggunaannya.

\section{Faktor Pendukung dalam Penggunaan Go Aplikasi untuk Meningkatkan Partisipasi Orangtua Peserta Didik}

Dalam mengimplementasikan program, ada beberapa faktor yang menjadi pendukung sekolah ketika pengunaan go aplikasi untuk meningkatkan partisipasi orangtua peserta didik. Faktor pendukung yang pertama yaitu mulai dari internal sekolah atau potensi sekolah itu sendiri. Faktor pendukung yang kedua dengan adanya tim TI sekolah dapat menciptakan, mengorganisir, dan mengimplementasi aplikasi. Faktor pendukung ketiga dari guru-guru mensosialisasikan kepada siswa mengenai kegunaan dan akhirnya dapat mengimplementasikan. Kemudian selain dari potensi sekolah atau dari orangtua juga mendukung dengan adanya perangkat go aplikasi banyak sekali manfaatnya karena orangtua dapat memantau anaknya tanpa harus datang ke sekolah, dan tidak mungkin melarang anak-anak agar tidak menggunakan $h p$ dengan perkembangan zaman ini.

Semua kegiatan pembelajaran yang ada di SMP Negeri 3 Malang sudah menggunakan pembelajaran berbasis TI, orangtua tidak mempunyai alasan untuk tidak berpartisipasi di sekolah karena mulai dari awal pendaftaran sekolah sudah memanfaatkan TI. Dengan adanya program sekolah yang melibatkan orangtua dapat menumbuhkan rasa tanggung jawab orangtua untuk berpartisipasi, sehingga orangtua selalu mencari informasi baru yang ada disekolah. Jika sekolah dirasa kurang sesuai apa yang diharapkan orangtua, orangtua dapat memberikan saran-saran baik secara langsung disekolah atau dapat melalui media yang sudah disediakan oleh sekolah. Dengan adanya peran komite, komite menyampaikan ke paguyuban-paguyuban yang ada di kelas mengenai program sekolah dan komite juga berperan sebagai pengontrol sekolah yang dapat menjadi faktor pendukung penggunaan go aplikasi untuk meningkatkan partisipasi orangtua peserta didik. 


\section{Faktor Penghambat dalam Penggunaan Go Aplikasi untuk Meningkatkan Partisipasi Orangtua Peserta Didik}

Tidak semua program dapat berjalan dengan lancar, salah satu faktor penghambat di SMP Negeri 3 Malang dalam penggunaan go aplikasi terdapat penghambat di dalamnya. Faktor penghambat yang dihadapi oleh sekolah berasal dari beberapa pihak, faktor penghambat itu berupa orang tua yang pasif, beberapa sumber daya manusia sekolah yang tidak muda lagi, kesibukan dari masing-masing pihak seperti orang tua peserta didik, dan sistem yang tidak dapat mengukur secara kualitas karya siswa. Beberapa kendala yang dihadapi sekolah terdapat solusi. Solusi dari masing-masing kendala tersebut adalah meningkatkan komunikasi atau beberapa pihak terkait terjun langsung untuk saling belajar bersama memanfaatkan TI ketika terdapat masalah mengenai gaptek, mengikutsertakan orangtua hadir di SMP Negeri 3 Malang untuk melakukan pendekatan dan memberi pengertian orang tua peserta didik mengenai program sekolah yang akan melibatkan orang tua peserta didik, dan orangtua dapat bertanya ke guru langsung atau bertanya ke keluarga yang lebih tahu.

\section{Penanganan atas Hambatan dalam Penggunaan Go Aplikasi}

Ketika sekolah itu sudah mempunyai kekuatan untuk menarik partisipasi orangtua, sekolah harus bisa mempertahankan yang sudah sesuai dengan semestinya agar tingkat kepercayaan orangtua itu semakin tinggi. Sedangkan kebalikannya jika tingkat partisipasi orangtua masih belum sesuai dengan yang diharapkan, sekolah harus mulai untuk menangani hambatan dari partisipasi khususnya pada penggunaan go aplikasi. Penanganan perangkat go aplikasi ini masih perlu untuk ditindak lanjuti atau ditangani agar lebih baik. Hal penanganan untuk perangkat go aplikasi, SMP Negeri 3 Malang memiliki keinginan atau rencana kedepannya untuk mengembangkan lebih baik lagi agar sekolah dapat menjadi daya tarik orangtua untuk tingkat partisipasinya meningkat dari sebelumnya.

Penanganan atas hambatan dalam penggunaan go aplikasi, kepala sekolah lebih berupaya untuk memotivasi warga sekolah untuk menggunakan TI sesuai dengan visi misi sekolah karena perkembangan zaman dari waktu ke waktu pasti akan berubah, kepala sekolah juga berencana untuk menambah variasi-variasi atau terobosan baru dalam perangkat go aplikasi agar pengguna dari go aplikasi merasa nyaman ketika membukanya, lebih memperbanyak frekuensi pertemuan atau diadakan pelatihan dalam penggunaannya, menghimbau peserta didik untuk tidak mengirim karya literasi tidak di hari Sabtu untuk menghindari kemacetan aplikasi, jika perangkat go aplikasi yang terdapat masalah akan di permudah lagi agar lebih praktis dan akan dipelajari oleh tim TI akan mempelajari terlebih dahulu bagaimana jika mengembangkan lebih baik lagi agar tidak ada masalah, dan perangkat go aplikasi butuh dievaluasi bagaimana merombak sistemnya agar lebih baik lagi.

\section{PEMBAHASAN}

\section{Proses Pengelolaan Go Aplikasi untuk Meningkatkan Partisipasi Orangtua Peserta Didik}

Sekolah dalam membangun hubungan dengan masyarakat memiliki program yang melibatkan masyarakat. Program yang ada yaitu go aplikasi, khususnya program tersebut tidak terkecuali mempunyai prosedur atau langkah-langkah untuk menjalankannya yang meliputi (1) proses perencanaan. (2) proses pengorganisasian. (3) proses pelaksanaan. Dan (4) proses evaluasi. Berdasarkan hasil penelitian menunjukkan bahwa proses dalam pengelolaan go aplikasi terdapat prosedur atau langkah-langkah untuk menjalankannya. Menurut Cutlip, dkk (2005) yang harus dilakukan dalam proses manajemen humas yaitu: (1) Mendefinisikan masalah; (2) Membuat rencana program; (3) Mengambil tindakan dan berkomunikasi; dan (4) Mengevaluasi program. Sementara Imron dan Sumarsono (2017) ada langkah-langkah yang harus dilakukan dalam proses manajemen humas yaitu (1) Perencanaan, (2) Pengorganisasian (3) Pengkomunikasian, (4) Pelaksanaan, dan (5) Pengevaluasian. Sedangkan dalam meningkatkan partisipasi menurut Benty dan Gunawan (2015) menyebutkan bahwa sekolah dalam meningkatkan partisipasi masyarakat dalam program pendidikan sekolah harus memahami tahapan dalam melaksanakan kerjasama dengan masyarakat. 
Berdasarkan proses pengelolaan go aplikasi untuk meningkatkan partisipasi dapat disimpulkan sekolah mempunyai dan memahami tahapan yang dilakukan untuk meningkatka partisipasi. Dalam meningkatkan partisipasi menurut Benty dan Gunawan (2015) menyebutkan bahwa sekolah dalam meningkatkan partisipasi masyarakat dalam program pendidikan sekolah harus memahami tahapan dalam melaksanakan kerjasama dengan masyarakat.

\section{Pemahaman Orangtua dalam Penggunaan Go Aplikasi sebagai Wadah Partisipasi}

Sekolah dalam meningkatkan partisipasi orangtua tentunya memiliki sebuah ide atau terobosan baru sebagai wadah untuk memberikan pemahaman kepada orangtua agar lebih antusias dalam berpartisipasi. Begitu pula dengan SMP Negeri 3 Malang mempunyai ide atau terobosan baru untuk memanfaatkan TI dan ditawarkan kepada orangtua peserta didik yaitu dengan menciptakan sebuah perangkat yang bernama go aplikasi yang berguna sebagai wadah partisipasi. Sama halnya dengan yang pemaparan Munir (2011:33) peranan teknologi informasi dan komunikasi ada tiga yaitu: menggantikan peran manusia dengan melakukan kegiatan otomasi suatu tugas atau proses tertentu; memperkuat peran manusia yaitu menyajikan informasi, tugas, atau proses; melakukan restrukturisasi atau melakukan perubahan terhadap suatu tugas atau proses.

Dalam diterapkannya go aplikasi, para orangtua juga tengah berupaya untuk memahami peranagkat go aplikasi yaitu dengan mengadakan komunikasi. Sesuai dengan pendapat Benty dan Gunawan (2015) fungsi humas yang harus dimiliki sekolah yaitu: (1) berusaha untuk mewujudkan tujuan bersama, (2) menciptakan hubungan yang harmonis dengan pihak masyarakat, (3) menciptakan komunikasi yang saling menguntungkan antara pihak sekolah dengan pihak masyarakat, (4) melayani kebutuhan masyarakat serta memberikan bantuan saran untuk kemajuan bersama, (5) mengidentifikasi serta memperhatikan segala sesuatu yang berkaitan dengan opini, tanggapan, serta persepsi masyarakat terhadap sekolah.

Setelah orangtua memahami go aplikasi dan fitur yang ada di dalamnya, orangtua mulai menggunakan go aplikasi sebagai wadah untuk berpartisipasi. Sama halnya dengan Minarti (2012) mengungkapkan bahwa bentuk kerjasama antara sekolah dengan masyarakat dapat digolongkan menjadi 3 hal, yaitu: (1) hubungan edukatif, (2) hubungan kultural, (3) hubungan institusional.

\section{Dampak Penggunaan Go Aplikasi bagi Sekolah dan Orangtua Peserta Didik}

Berkaitan dengan faktor pendukung dan penghambat tentunya akan muncul sebuah dampak dari penggunaan go aplikasi yang ada di sekolah. Dari dampak tersebut tidak semuanya dapat menjadi dampak yang positif, tetapi ada juga dampak yang negatif. Dari dampak yang positif dapat dirasakan dengan semua warga sekolah dipacu untuk menggunakan TI, guru-guru dapat mengembangkan diri dengan memanfaatkan TI, terbantunya proses pembelajaran, mempersingkat waktu, dan yang dirasakan oleh orangtua yaitu mudahnya mendapat informasi dari sekolah. Sedangkan dampak negatif yang dirasakan sekolah dan orangtua atas penggunaan go aplikasi adalah proses implementasinya membutuhkan waktu, penggunaan handphone yang tidak sesuai koridor jika tidak di kontrol di sekolah maupun di rumah dengan orangtua.

Sesuai dengan penelitian yang dilakukan oleh (Nurabadi, 2014) mengenai ketersediaan dan pemanfaatan teknologi informasi dalam peningkatan mutu pembelajaran menemukan bahwa tingkat pemanfaatan teknologi informasi cukup tinggi dan berkat adanya teknologi informasi sangat membantu proses pelaksanaan pembelajaran yang efektif, sehingga peningkatan mutu pembelajaran dapat terwujud. Sedangkan menurut dampak negatif menurut (Sudibyo, 2011) antara lain: (1) E-learning yang dapat pengalihfungsian dan mengakibatkan guru jadi tersingkirkan, (2) Seringnya mengakses internet dikhawatirkan peserta didik menyalahgunakan, (3) Peserta didik dapat terkena information overload, (4) Peserta didik menjadi pecandu dunia maya secara berlebihan, (5) Tindakan criminal, (6) Menimbulkan sikap apatis baik bagi peserta didik, guru, ataupun orangtua.

\section{Faktor Pendukung dalam Penggunaan Go Aplikasi untuk Meningkatkan Partisipasi Orangtua Peserta Didik}

Dalam mengimplementasikan program, ada beberapa faktor yang menjadi pendukung sekolah ketika pengunaan go aplikasi untuk meningkatkan partisipasi orangtua peserta didik. Faktor pendukung 
merupakan keadaan atau peristiwa yang mempengaruhi atau menyebabkan terjadinya beberapa pihak untuk menunjang, menyokong, membantu yang sifatnya ikut serta, dan sebagainya. Faktor pendukung yang dialami sekolah yaitu dengan adanya potensi sekolah. Sama seperti yang dipaparkan oleh Sumarto (2004:188) faktor pendukung partisipasi masyarakat ada empat yaitu: 1) Kepentingan, dalam hal ini berarti adanya kepentingan tertentu dari seseorang, akan mampu mendorong seseorang ikut berpartisipasi dalam suatu kegiatan tertentu; 2) Solidaritas, rasa solidaritas yang tinggi akan mendorong seseorang untuk ikut aktif dan berpartisipasi dalam menjalankan suatu program tertentu; 3) Tujuan yang sama, partisipasi dan keaktifan seseorang dalam kegiatan tertentu dapat didorong dengan adanya tujuan yang sama; 4) dan ingin melakukan langkah bersama, walau tujuannya berbeda.

Faktor pendukung dalam meningkatkan partisipasi orangtua peserta didik dengan menggunakan go aplikasi juga disertai dengan adanya kemauan dari pengguna untuk mencapai tujuan. Sebagaimana yang dikemukakan oleh Olsen \& Fuller dalam Imron dan Sumarsono (2017) mengungkapkan bahwa partisipasi orangtua dapat dimaknai sebagai suatu proses aktif dan sebagai suatu kegiatan nyata apabila terpenuhi oleh ketiga faktor pendukungnya, yaitu: (1) adanya kemauan, (2) adanya kemampuan, dan (3) adanya kesempatan untuk berpartisipasi.

\section{Faktor Penghambat dalam Penggunaan Go Aplikasi untuk Meningkatkan Partisipasi Orangtua Peserta Didik}

Tidak semua program dapat berjalan dengan lancar, salah satu faktor penghambat di SMP Negeri 3 Malang dalam penggunaan go aplikasi terdapat penghambat di dalamnya. Disamping terdapat faktor penghambat pasti juga terdapat solusi dari faktor penghambat tersebut. Faktor penghambat yang dihadapi oleh sekolah berasal dari beberapa pihak. Faktor penghambat itu berupa orang tua yang pasif karena jarang membuka aplikasi yang menyebabkan tidak tersampainya informasi, beberapa sumber daya manusia sekolah yang tidak muda lagi, kesibukan dari masing-masing pihak seperti orang tua peserta didik. Sesuai dengan Dwiningrum (2011: 90) salah satu faktor yang dapat menghambat partisipasi ialah sifat malas, apatis, masa bodoh, dan tidak mau melakukan perubahan di tingkat anggota masyarakat.

Solusi SMP Negeri 3 Malang dari masyarakat atau orang tua yang pasif yakni dengan mengkomunikasikan program yang dirasa menjadi hambatan orangtua atau dengan beberapa pihak yang turut membantu untuk saling belajar bersama memanfaatkan TI ketika terdapat masalah mengenai gaptek, mengikutsertakan orangtua hadir di sekolah untuk melakukan pendekatan dan memberi pengertian orang tua peserta didik mengenai program sekolah yang akan melibatkan orang tua peserta didik, dan orangtua dapat bertanya ke guru langsung atau bertanya ke keluarga yang lebih tahu. Sesuai dengan pendapat Fuad (2012:50) tingkat partisipasi masyarakat dalam pendidikan juga dapat berupa pemberian support seperti dukungan dana dan tenaga, serta keterlibatan dalam pengambilan keputusan. Sedangkan menurut Cohen dan Uphoff dalam Dwiningrum (2011:61) membedakan partisipasi menjadi empat jenis, yaitu (1) partisipasi dalam pengambilan keputusan, masyarakat dapat ikut mengambil keputusan yang berkaitan dengan proses menuju kesepakatan suatu forum. (2) Partisipasi dalam pelaksanaan, masyarakat dibutuhkan untuk keterlibatan dalam pelaksanaan suatu kegiatan yang dilaksanakan. (3) Partisipasi dalam pengambilan pemanfaatan, partisipasi ini terlepas dari kualitas maupun kuantitas hasil pelaksanaan program yang bisa dicapai, dan (4) partisipasi dalam evaluasi, masyarakat dalam partipasi ini berkaitan dengan masalah pelaksanaan program. Partisipasi ini bertujuan untuk mengetahui pelaksanaan program telah sesuai atau tidak.

\section{Penanganan atas Hambatan dalam Penggunaan Go Aplikasi}

Sekolah dapat menangani atas hambatan dengan berbagai upaya. Ketika sekolah itu sudah mempunyai kekuatan untuk menarik partisipasi orangtua, sekolah harus bisa mempertahankan yang sudah sesuai dengan semestinya agar tingkat kepercayaan orangtua itu semakin tinggi. Salah satu cara yang dilakukan sekolah untuk menangani hambatan dalam penggunaan go aplikasi yakni, kepala sekolah berupaya untuk memotivasi warga sekolah untuk menggunakan TI sesuai dengan visi misi sekolah. Kepala sekolah juga berencana untuk menambah variasi-variasi atau terobosan baru dalam perangkat go aplikasi agar pengguna dari go aplikasi merasa nyaman ketika membukanya, lebih memperbanyak 
frekuensi pertemuan atau diadakan pelatihan dalam penggunaannya, menghimbau peserta didik untuk tidak mengirim karya literasi tidak di hari Sabtu untuk menghindari kemacetan aplikasi.

Penanganan sekolah memotivasi, menghimbau, menambah terobosan baru, dan mengadakan pelatihan merupakan salah satu kunci untuk mengatasi hambatan yang ada. Menurut hasil penelitian Nurlaiva dan Sumarsono, (2018)phenomenological approach, with a case study design in Private Vocational School 1 Muhammadiyah Malang (SMK 1 Muhammadiyah Malang menunjukkan bahwa $\mathrm{n}$, khususnya bagaimana kepala sekolah dalam memimpin agar partisipasi orangtua dapat terwujud dan terpelihara. Sehingga masyarakat yang telah memahami dan mempunyai tanggung jawab penuh, tidak akan adanya berbagai kesulitan dalam mengembangkan program yang telah direncanakan oleh sekolah.

\section{SIMPULAN}

Berdasarkan dari temuan penelitian adalah sebagai berikut: (1) Proses dalam pengelolaan Go Aplikasi untuk meningkatkan partisipasi orangtua peserta didik terdapat kegiatan dari perencanaan, pengorganisasian, pelaksanaan, dan evaluasi; (2) Pemahaman orangtua dalam penggunaan Go Aplikasi sebagai wadah partisipasi terdapat memudahkan pekerjaan, adanya komunikasi, dan orangtua berpartisipasi; (3) Dampak penggunaan Go Aplikasi bagi sekolah dan orangtua peserta didik terdapat dampak positif yaitu warga sekolah terpacu menggunakan IT, terbantunya proses pembelajaran, mudah dan mempersingkat waktu. Sementara itu untuk dampak negatif adalah proses implementasinya membutuhkan waktu dan penggunaan handphone yang tidak sesuai koridor; (4) Faktor pendukung dalam penggunaan Go Aplikasi untuk meningkatkan partisipasi orangtua peserta didik dengan adanya potensi sekolah yang meliputi kepala sekolah, tim TI, guru, komite, orangtua, dan siswa; (5) Faktor penghambat dalam penggunaan Go Aplikasi dan solusinya terdapat orangtua yang pasif, SDM tidak muda lagi, kesibukan orangtua dan terdapat solusi dengan adanya komunikasi dan datang ke sekolah; (6) Penanganan atas hambatan dalam penggunaan Go Aplikasi dengan memotivasi, menambah variasi, adanya pelatihan, dan himbauan.

\section{DAFTAR PUSTAKA}

Benty, D.D.N \& Gunawan, I. 2015. Manajemen Hubungan Sekolah dan Masyarakat. Malang: Universitas Negeri Malang

Cutlip, S.M, DKK. 2005. Effective Public Relation Merancang Dan Melaksanakan Kegiatan Kehumasan Dengan Sukses. Jakarta: PT INDEKS Kelompok Gramedia

Dwiningrum, S.I.A. 2011. Desentralisasi dan Partisipasi Masyarakat dalam Pendidikan. Yogyakarta: Pustaka Belajar.

Fuad, N. 2012. Manajemen Pendidikan Berbasis Masyarakat. Jakarta: FIP PRESS.

Gleason, J.P., Violette, J.L., 2012. Integrating Service Learning into Public Relations Coursework: Applications, Implications, Challenges, and Rewards 6.

Imron, A dan Sumarsono, R.B. 2017. Manajemen Hubungan dan Partisipasi Masyarakat di Sekolah. Malang: Universitas Negeri Malang

Minarti, S. 2012. Manajemen Sekolah: Mengelola Lembaga Pendidikan Secara Mandiri. Yogyakarta: Ar-Ruzz Media

Munir. 2011. Pembelajaran Jarak Jauh Berbasis Teknologi Informasi dan Komunikasi. Bandung: Alfabeta

Ng, S.W. 2013. Including parents in school governance: rhetoric or reality. Int. J. Educ. Manag. 27, 667-680. https://doi.org/10.1108/IJEM-07-2012-0087

Nugroho, M.A., n.d. Pemanfaatan Teknologi Informasi dalam Peningkatan Mutu Pendidikan Islam di Madrasah 6,31 .

Nurabadi, A., 2014. Ketersediaan Dan Pemanfaatan Perangkat Teknologi Informasi (Ti) Dalam Peningkatan Mutu Pembelajaran. Jurnal Manajemen Pendidikan Volume 24, Nomor 3, Maret 2014: 221-227. (Online). http:// ap.fip.um.ac.id/wp-content/uploads/2015/05/volume-24-no.-345-51.pdf. Diakses pada 23 Maret 2018 
Nurlaiva, C., Sumarsono, R.B., 2018. Community Participants in Managing Education Programs in Vocational School, in: Proceedings of the 3rd International Conference on Educational Management and Administration (CoEMA 2018). Presented at the 3rd International Conference on Educational Management and Administration (CoEMA 2018), Atlantis Press, Malang, Indonesia. https://doi.org/10.2991/coema-18.2018.51

Sudibyo, L., 2011. Peranan dan Dampak Teknologi Informasi dalam Dunia Pendidikan di Indonesia. Jurnal WIDYATAMA Universitas Veteran Bangun Nusantara Sukoharjo. Vol 20, No:182

Sumarsono, R.B., 2019. UPAYAMEWUJUDKAN MUTU PENDIDIKAN MELALUI PARTISIPASI ORANGTUA SISWA. J. Ilmu Pendidik. 24, 63. https://doi.org/10.17977/um048v24i2p63-74

Sumarsono, R.B., Imron, A., Wiyono, B.B., Arifin, I., 2016. Parents' Participation in Improving the Quality of Elementary School in the City of Malang, East Java, Indonesia. Int. Educ. Stud. 9, 256. https://doi.org/10.5539/ ies.v9n10p256

Sumarto, H SJ. 2004. Inovasi, Partisipasi dan Good Governance. Jakarta: Yayasan Obor Indonesia

Usman, A.S., 2014. Meningkatan Mutu Pendidikan Melalui Penerapan Manajemen Berbasis Sekolah. Jurnal Ilmiah DIDAKTIKA 2014 VOL. 15, No. 1, 13-31. (Online). https://jurnal.ar-raniry.ac.id/index.php/didaktika/ article/view/554/457. Diakses pada 24 Januari 2018 